\title{
Commercial coral-reef fisheries across Micronesia: A need for improving management
}

\author{
P. Houk $\cdot$ K. Rhodes $\cdot$ J. Cuetos-Bueno $\cdot$ \\ S. Lindfield · V. Fread $\cdot$ J. L. McIlwain
}

Received: 2 February 2011 / Accepted: 6 September 2011/Published online: 25 September 2011

(c) Springer-Verlag 2011

\begin{abstract}
A dearth of scientific data surrounding Micronesia's coral-reef fisheries has limited their formal assessment and continues to hinder local and regional management efforts. We approach this problem by comparing catch-based datasets from market landings across Micronesia to evaluate fishery status in the Commonwealth of the Northern Mariana Islands (CNMI), Guam, Yap, and Pohnpei. Initial examinations found that calm weather and low lunar illumination predicted between $6 \%$ (Yap) and $30 \%$ (CNMI) of the variances in daily commercial landings. Both environmentally driven catch success and daily catch variability increased in accordance with reef-fish demand indices. Subsequent insight from species composition and size-at-capture data supported these findings, highlighting
\end{abstract}

Communicated by Biology Editor Dr. Stephen Swearer

P. Houk $(\bowtie)$

Pacific Marine Resources Institute, Saipan, MP 96950, USA

e-mail: peterhouk@pacmares.com

K. Rhodes

College of Agriculture, Forestry and Natural Resource

Management, University of Hawaii at Hilo,

Hilo, HI 96720, USA

J. Cuetos-Bueno

Scripps Institution of Oceanography, La Jolla, CA 92093, USA

\section{S. Lindfield}

The UWA Oceans Institute and School of Plant Biology, The University of Western Australia, Crawley, WA 6009, Australia

V. Fread

Yap Community Action Program, Colonia, YAP 96943, USA

J. L. McIlwain

University of Guam Marine Laboratory, Mangilao,

Guam 96923, USA reduced trophic levels and capture sizes where higher human-population-per-reef-area existed. Among the 12-15 target species and/or species complexes that accounted for $70 \%$ of the harvest biomass, capture sizes were consistently smallest for CNMI and Guam, often below the reported mean reproductive sizes. Comparatively, Pohnpei has the greatest potential for reef fisheries, with a large reef area $\left(303 \mathrm{~km}^{2}\right)$ and a moderate human population $(34,000$ people). However, the estimated harvest volume of $476 \mathrm{mt}$ year $^{-1}$ was 8-9 times higher than other jurisdictions. Even on Yap where the reef-fish demand index was lowest (67.7 people $\mathrm{km}^{-2}$ reef habitat), many target fish were harvested below their mean reproductive sizes, including the iconic green bumphead parrotfish and humphead wrasse, as well as several other herbivores. We discuss our results with respect to the contemporary doctrine surrounding size-spectra, catch composition, and catch frequencies that afford insight into fishery pressure and status. We posit that regional catch-based policies (initially) instituted at the market level, combined with area and gear-based restrictions, represent plausible vectors for improving Micronesian fisheries.

Keywords Coral-reef fisheries · Fishery-dependent data . Commercial markets $\cdot$ Micronesia $\cdot$ Fishery management

\section{Introduction}

While many coral-reef fisheries are exploited beyond a level considered sustainable (Newton et al. 2007), the true extent of sustainability is difficult to gauge because fish landings are often insufficiently documented, or unreported (Zeller et al. 2006). Throughout Micronesia, one of the greatest challenges for fisheries management has been the dearth of reliable data that are essential for the evaluation 
of exploitation status and policy (Dalzell et al. 1996). Consequently, contemporary catches from Micronesian reef fisheries remain largely unrestrained by effort or other catch-control policies. The wealth of traditional marine tenure that once existed throughout the region continues to erode, in part, because it does not account for the commercialization of marine resources (Johannes 1978; Sudo 1984; Dahl 1988; Rhodes et al. 2008; Brewer et al. 2009). Currently, a shift to open access resource exploitation is increasing together with commercialization. Meanwhile, the catch value continues to decline relative to inflation and the cost of commercial goods, and more effort is required to meet the financial needs of fishers (Johannes 1978; Graham 1992, 1994; Rhodes et al. 2008). While self-reinforcing mechanisms are driving harvest volumes up, many desirable reef fish are known to have slow growth and late reproductive maturation (Choat et al. 1996; Birkeland 2004; Heupel et al. 2010). The consequences of ensuing fishery depletions include reduced ecological functions and altered trophic structures that threaten coral-reef integrity and resilience (Folke et al. 2004; Cinner and McClanahan 2006; Houk et al. 2010), as well as social structure (Costanza et al. 1997; Brander et al. 2007).

Like any complex system, multi-species fisheries are dynamic (May 1977; Caddy and Seijo 2005) and respond to environmental cues ranging from daily changes in wind, waves, and lunar illumination (Johannes 1981; Rhodes et al. 2008) to long-term global and regional shifts in oceanographic and atmospheric conditions (McClanahan et al. 2002). While environmental patterns are known to influence fisheries dynamics over short time-scales (i.e., moon phase within a month or productivity within a year; McClanahan 1988; Kaunda-Arara et al. 2009), long-term dynamics are more dependent upon fishing effort and individual species' life histories (Pauly et al. 1998; Tsehaye et al. 2007). Disentangling the relationships between shortterm seasonal changes and long-term trends continues to be a central focus for fisheries research (May et al. 1979; Hsieh et al. 2006; Anderson et al. 2008a). The current doctrine supports that as fishing intensity increases, shifts in population and community structure become evident (Jennings and Greenstreet 1999; Graham et al. 2005), and stock variability increases due to a tightening of feedback loops between environmental regimes and fish stocks (Anderson et al. 2008a). In summary, desirable fish landings become more reliant upon favorable environmental and/or temporal regimes and eventually decline as this reliance builds. Shifting fisheries have been reported in Jamaica (Koslow et al. 1988), Seychelles (Jennings and Kaiser 1998), Kenya (Kaunda-Arara et al. 2003), and trends are now becoming increasingly prevalent for Micronesia (Zeller et al. 2007; Rhodes et al. 2008; Richmond et al. 2008). Together, these concepts form the basis for the present investigation.
We improve upon the lack of quantitative fisheries data from Micronesia by combining catch-based datasets across CNMI, Guam, Yap, and Pohnpei, to evaluate indicators of fishery status. This study is inclusive of over 50,000 fish measurements from the commercial markets and fisher catches, providing an extensive snapshot in time. We initially examine the degree to which favorable environmental regimes, proxies of fishing intensity, and marketed fish value explained the observed catch dynamics. We hypothesize that a higher reliance upon favorable environments for good catches, and higher variability in daily landings coincide with increased fish demand (Anderson et al. 2008a; McClanahan et al. 2008). We further posit that reduced trophic levels and decreased mean size-at-capture for targeted reef fish will be most pronounced where high proxies to fishing pressure exist (Jennings and Polunin 1996; Jennings and Greenstreet 1999; Graham et al. 2005). To our knowledge, this study represents the first peerreviewed assessment of size and species-based catch data throughout Micronesia, and the Western Pacific, and highlights a need for more robust fishery-dependent data collection and reporting.

\section{Methods}

\section{Study locations}

This study utilized catch-based datasets from market landings to assess the status of shallow $(0-30 \mathrm{~m})$ coral-reef fisheries across four Micronesian jurisdictions: Commonwealth of the Northern Mariana Islands (CNMI), Guam, Yap, and Pohnpei (Fig. 1).

Guam and CNMI are southern islands in the Mariana Archipelago and represent major population centers in Micronesia with populations of 150,000 and 70,000 reported in the 2000 census, respectively (Table 1). Both include major tourism sectors with 1,100,000 and 400,000 visitors reported in 2010. Due to their higher latitude, seasonal weather patterns in the Marianas are well defined by fluctuations in trade winds, ocean swells, and rainfall between winter and summer months (Fig. 1; Eldredge 1983). Reef area throughout Guam and the southern CNMI islands (Saipan, Tinian, Aguijan, and Rota) is relatively small compared with the other Micronesian jurisdictions examined, due to the absence of extensive lagoon systems lined with barrier reefs (Table 1). However, Saipan Lagoon in the CNMI and Cocos Lagoon in Guam make notable contributions to overall reef area. Recent surveys estimated that between 20 and $40 \%$ of households actively participate in subsistence and recreational fisheries (van Beukering et al. 2006, 2007), comparatively lower than other study jurisdictions, while $60-70 \%$ of the consumed seafood was 


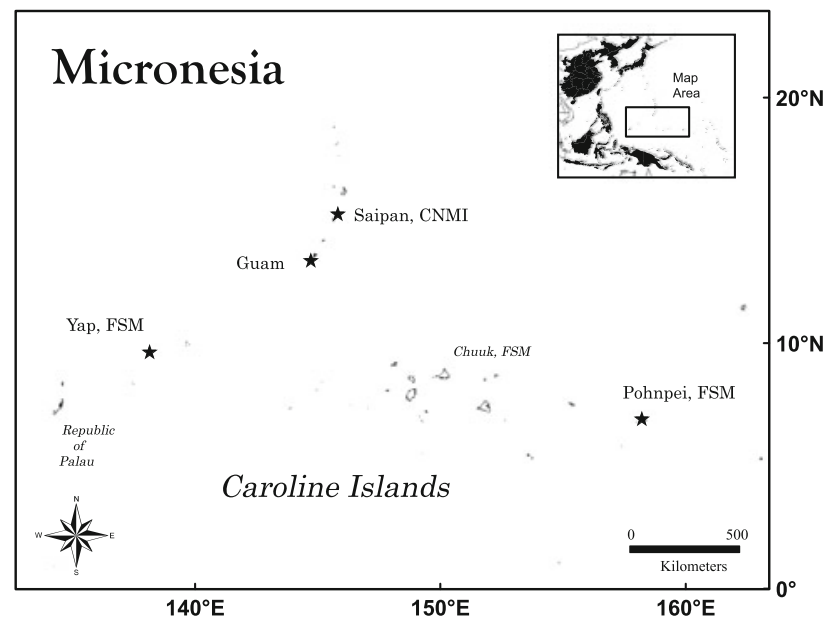

Fig. 1 Map of Micronesia highlighting the study regions

purchased at commercial establishments on Guam and Saipan (the capital of CNMI). An informal inquiry of airline cargo statistics revealed that both jurisdictions have substantial imports of reef fish for personal consumption and/or sales, which greatly exceed exports. In both cases, marine resources follow an open-access harvesting policy with Guam being the only island where SCUBA spearfishing remains legal and is responsible for a large part of the commercial reef catch. While area and gear-based restrictions exist, there are no provisions regarding the amount or size of reef fish being harvested for the majority $(>70 \%)$ of the reefs.

Yap is the westernmost state in the Federated States of Micronesia (FSM) and has the lowest human population (6,300 on Yap Proper) and a moderate reef size (Table 1). Yap has an extensive lagoon system, comprised of mangroves, seagrass beds, patch reefs, sand flats, and outer reef habitats. Commercial reef fisheries are least developed on Yap, as recent household surveys indicated that there were on average two subsistence fishers per household, and that much of the seafood consumed was either caught or offered as a gift (Kronen and Tafileichig 2008). However, reef-fish sales and exports have a long history of growth, along with increasing costs for imported food, fuel, and manufactured goods (Graham 1992). Yap is the only jurisdiction in this study where a traditional form of marine tenure still exists. Marine resources remain owned and managed by traditional leaders and their respective communities (Graham 1992; Kronen and Tafileichig 2008). Several community-based marine protected areas have been established, but no other policies regarding size or quantity of fish being harvested exist.

Pohnpei is the capital of FSM, with over 34,000 people residing on the main island, and an open-access fishery policy similar to Guam. Pohnpei has the largest coral reef area among the jurisdictions examined (Table 1), encompassing a large lagoon with similar habitats noted on Yap. Recent interviews estimated that $63 \%$ of households have at least one fisher, with an overall average of 1.3 fishers per household (Hopkins and Rhodes 2010), while 33\% of consumed reef fish were purchased. These trends indicate moderate subsistence and recreational fishery use that is lower than Yap, but higher than CNMI and Guam. Reef fish export was estimated at $20 \mathrm{mt} \mathrm{year}^{-1}$ based upon records from individual travelers going mainly to Guam or Hawaii (Hopkins and Rhodes 2010). There is a seasonal ban on grouper sales between 1 March and 30 April, and a complete ban on the sale of adult green bumphead parrotfish, Bolbometopon muricatum. Several no-take marine protected areas exist in the state, and fishing with explosives and chemicals is prohibited. SCUBA spearfishing is not prohibited, although its use on the island for fishing is rare based upon fishermen interviews.

\section{Data collection}

Datasets used in this study originated from independent collection efforts. In the CNMI, catch data were collected

Table 1 Relevant statistics and indices calculated for each jurisdiction

\begin{tabular}{|c|c|c|c|c|}
\hline & Definition & CNMI & Pohnpei & Yap \\
\hline Reef area & $\mathrm{km}^{2}$ & 134.6 & 303 & 93.1 \\
\hline Human population & \# of people reported in 2000 census & 69,221 & 34,000 & 6,300 \\
\hline Marketed fish biomass & Estimated annual marketed catch $(\mathrm{kg})$ & 54,545 & 476,000 & 59,962 \\
\hline Estimated frequency of catch method & $\%$ Night-spear:\% hook and line: $\%$ net: $\%$ other & $85: 12: 0: 3$ & $75: 20: 5: 0$ & 80:10:10:0 \\
\hline Local cost of fish & Price (USD\$ per kg) & $\$ 8.25$ & $\$ 2.75$ & $\$ 2.5$ \\
\hline Estimated value of annual catch & Market price $*$ annual catch $(\$)$ & $\$ 449,996$ & $\$ 1,309,000$ & $\$ 149,905$ \\
\hline Harvest yield & Annual market catch/reef area $\left(\mathrm{kg} \mathrm{km}^{-2}\right)$ & 405.2 & $1,570.9$ & 644.5 \\
\hline Reef fish demand index & (Human population/reef area) (person $\mathrm{km}^{-2}$ ) & 514.2 & 112.2 & 67.7 \\
\hline Realized reef-fish value index & (Annual market catch $*$ cost per $\mathrm{kg}$ )/reef area $\left(\$ \mathrm{~km}^{-2}\right)$ & 3,343 & 4,320 & 1,611 \\
\hline
\end{tabular}

See methods for a description of the calculated statistics. Market price represents the mean value for all reef fish, and while some reef fish are preferentially sold for higher prices, the mean value used represents the cost associated with the majority of reef fish 
between June and September, 2009, and again between December and January, 2009, in order to generate representative estimates for the summer and winter seasons. Daily visits were made to four of the seven primary, Saipan-based markets. During each visit, all reef fish present were identified to the highest taxonomic resolution possible and measured to the nearest $\mathrm{cm}$ fork length (FL). In a few instances, species complexes were used when species-level identifications were not possible. Examples include initial growth phases of juvenile goatfish (Parupeneus spp.) and some parrotfish (Scarus spp.). During each visit, interviews were conducted with vendors or fishers to determine catch methods and island of origin (Tinian and Aguijan were grouped together because they were most often fished and reported as such due to their proximity). Annual total marketed biomass was estimated by calculating mean daily catch rates as a basis, and then extrapolating to account for the total number of markets $(n=7)$. Because seasonal differences in mean windspeed and wave height were significant predictors of daily biomass, and summer/winter seasons are well defined for CNMI (Eldredge 1983), annual extrapolations were adjusted for known environmental correlates.

In Guam, the Division of Aquatic and Wildlife Resources (DAWR), in collaboration with the Western Pacific Fisheries Information Network (WPacFIN), has conducted creel surveys since the mid 1980s that include documenting fish species, individual size measurements, fishing methods, and effort. This study utilized reef-fish data that were collected from two separate creel surveys; a boat-based (offshore) and a shore-based (inshore) survey. Because the interview program collects data prior to sale or consumption, no estimations for marketed landings were possible; however, the size-at-capture data are comparable with other jurisdictions. Because of a lack of SCUBAbased fishing reports from 2006 to present, this study evaluated the most recent and complete 6-year dataset (2000-2005).

In Yap, marketed reef fish were surveyed from July 5 to December 15, 2008, from the prominent fish vendor, in addition to two smaller, intermittent vendors, that sold fish approximately 1-2 times per week. All fishers encountered during visits were interviewed to gain insight into their catch methods, location, gear used, and number of fishers participating in each trip. All reef fish were identified using local names and measured to the nearest $\mathrm{cm}$ FL. Local names were later matched with their Latin counterparts using the highest taxonomic resolution possible. Examples include definitive species names for charismatic fish such as the bluespine unicornfish (Naso unicornis), green bumphead parrotfish (Bolbometopon muricatum), and humphead wrasse (Cheilinus undulatus), while other Yapese names indicated species complexes (i.e., Plectropomus spp.,
Kyphosus spp., and adult Chlorurus spp.). Annual catch biomass was estimated by combining extrapolations from the single, prominent market, as well as for 10 intermittent markets that were known to exist, across the year. Because regression analyses found little influence of wind or wave height in predicting daily biomass, no adjustments were made for seasonality.

In Pohnpei, marketed catch volumes were recorded from an average of 22 (of 31 total) markets between January 2006 and January 2007 (Rhodes and Tupper 2007; Rhodes et al. 2008). All fishers encountered during visits were interviewed to determine their catch methods and gear type, location, and number of fishers participating in each trip. Individual catches were separated by family and weighed. Size data were collected for the squaretail coralgrouper only, Plectropomus areolatus, as part of a separate study (Rhodes and Tupper 2007). Annual marketed catch biomass was estimated using the mean daily catch data and extrapolated to account for the total number of markets. Because regression analyses found little influence of wind or wave height in predicting daily biomass, no adjustments were made for seasonality when estimating annual catch biomass.

Cumulatively, all relevant catch-based datasets that were known to exist and made available to the authors were incorporated. The WPacFIN, in collaboration with local fisheries management agencies, provides monthly commercial landings for both Guam and CNMI, but several limitations exist: (1) the reporting of commercial landing data remains voluntary and (2) the majority of reef-fish records were grouped into an 'unknown' category (67\% of reef fish were reported as unknown in Guam during 2008). Hence, these data could not be used to detect differences at the family level or size-at-capture.

\section{Physical and environmental parameters}

Comparative indices of reef-fish demand, value, harvest yield, and several island-based statistics were generated (Table 1). This study defined coral-reef area as all reefassociated habitats that existed between 0 and $30 \mathrm{~m}$ depth, inclusive of lagoons, reef flats, and seagrass beds. Reef area was calculated by drawing polygons over high-resolution satellite imagery to a visually estimated $30 \mathrm{~m}$ depth; however, in the case of CNMI, available bathymetric data were used to define this contour. Daily tidal and lunar data were collected from freely available prediction software (http://www.wtides.com/), while daily wave height, wind speed, and rainfall data were collected from satellitederived estimations, available through the AVISO project (http://www.aviso.oceanobs.com/). Finally, human population data were collected from the 2000 census estimates that were available for all jurisdictions and individual 
islands. We note that our calculated metrics of harvest yield, demand, and value (Table 1) are based on annual marketed biomass estimates, and provide a context for relative comparisons. Absolute evaluation and assessments of these metrics would require the integration of subsistence and export catch volumes.

\section{Data preparation}

The goal of this study is to draw on the most extensive set of regional data, while recognizing the limitations that existed. For Guam, fisher interviews were too few to generate robust estimates of daily biomass or percent contribution by fish family, preventing regional comparisons of these summary statistics. However, species-based, demographic comparisons were made possible by pooling the creel data across several years to generate adequate sample sizes, while keeping timeframes in context. In contrast, combined weights of fish families from market landings in Pohnpei were appropriate for examining daily biomass and percent contribution by family; however, no demographic comparisons were available.

\section{Data analyses}

This study initially compiled daily landing estimates for regional comparisons and examinations with respect to environmental regimes. Jurisdictional comparisons were conducted using a consistent subset of data, representing the calmer summer months that provide the most extensive access to the fisheries (May to October). Daily marketed biomass data were log-transformed to meet assumptions of normality and homogeneity of variances, which were both confirmed using Shapiro-Wilk and Levene tests, respectively (Zar 1999). Because significant differences in daily catch variability were evident, non-parametric comparisons were made (Kruskal-Wallis and Dunn's tests). Environmental examinations were conducted using multiple regression models to determine the extent that percent lunar illumination (i.e., percent of lunar exposure regardless of phase), lunar phase (i.e., moon age regardless of exposure), wind speed, wave height, and rainfall predicted daily landings ( $R$ statistical package, Crawley 2007). Regression models were investigated for Yap, Pohnpei, and CNMI, where daily landing data were available. Best-fit models are presented in hierarchical order corresponding with their Akaike's information criterion (AIC) value. Briefly, the selected models explained the greatest proportion of variance, while using the least number of explanatory variables to ensure precision, accuracy, and repeatability (Crawley 2007). AIC weightings were provided for comparative purposes and can be interpreted as probabilities for selecting best-fit models.
Descriptive catch-based comparisons for Pohnpei, CNMI, and Yap were conducted using a multivariate approach to investigate differences in daily marketed fish composition (Table 1; PERMANOVA testing; Anderson et al. 2008b). For these analyses, data collected in Pohnpei between March and April were removed because they represent months when grouper sales were banned. Initial homogeneity of dispersion tests (PERMDISP) were conducted to ensure that comparisons were isolated upon the variance of interest, the separation of groups (islands), rather than differences in dispersion within any group. In cases where pairwise comparisons yielded non-homogeneous dispersion, non-parametric rank-based testing for island separation was conducted (ANOSIM, Clarke and Warwick 2001). ANOSIM tests are evaluated based upon R statistics between -1 and 1 that infer a degree of separation, with values $>0.5$ representing significant site separation (Clarke and Warwick 2001). Principal component ordination (PCO) was used to graphically interpret the separation of multivariate catch data in two dimensions. Vector overlays highlight fish families that had the greatest influence on data dispersion based upon Spearman's correlation coefficients between each fish family and the PCO axes.

Six target species that accounted for a consistently high proportion of the landed biomass across all jurisdictions were selected for size-at-capture comparisons, as well as for comparisons against their reported mean size at maturity (i.e., $\left.L_{50}\right)$. These species were Acanthurus xanthopterus, Naso unicornis, Monotaxis grandoculis, Hipposcarus longiceps, Chlorurus microrhinos, and Kyphosus spp. (K. cinerascens and $K$. vaigiensis were grouped due to a lack of taxonomic resolution in Yapese name translations). Mean reproductive size estimates were generated using the Fishbase life-history modeling tool (www.fishbase.org). This tool uses length at first maturity and asymptotic length (i.e., $\left.L_{\text {infinity }}\right)$ to estimate mean reproductive size, along with standard error (Froese and Binohlan 2000). Asymptotic fish lengths were taken from the combined datasets, while length at first maturity estimates originated from Fishbase reports. In the case of Kyphosus spp., size-at-reproduction estimates were calculated as the mean between the two species. Green Bumphead parrotfish, B. muricatum, and humphead wrasse, Cheilinus undulatus, were only landed in sufficient numbers in Yap to investigate population distributions. $L_{50}$ estimates for these two fish were derived from the recent literature (Hamilton et al. 2008; Sadovy de Mitcheson et al. 2010).

Statistical testing was conducted to examine the differences between species' populations from each jurisdiction, and against the $L_{50}$. In order to examine differences against the $L_{50}$, random normal distributions were generated using the calculated means and error margins ( $R$ statistical package, Crawley 2007). Despite data transformations, attempts to achieve required data normality and heterogeneity for 
parametric statistical comparisons between jurisdictions failed; however, statistical assumptions were often met when examining individual distributions against the $L_{50}$. Nonparametric rank tests were used to examine significance differences if statistical assumptions could not be met, while students t-tests were preferentially used elsewhere.

Finally, fish with a disproportionally high biomass-tooccurrence ratio were graphed to identify economically and ecologically influential species that are caught less frequently. Only species with a frequency of encounter greater than $0.25 \%$ were considered for each jurisdiction.

\section{Results}

Catch methods

Based upon fisher and market interviews, the majority $(>75 \%)$ of marketed reef fish in Micronesia originated from nighttime spearfishing (Table 1). While day spearfishing was noted, its comparative use for commercial fisheries was minimal. Gillnet fishing was recorded everywhere but the CNMI where it is illegal without cultural exemption, however, its use was considerably less than other gear types. Similarly, hook-and-line fishing constituted a small proportion of the marketed, shallow-water reef fish examined (approximately 10-20\%, Table 1).

\section{Biomass comparisons}

The annual landings of marketed reef fish varied considerably. Although Pohnpei has the greatest reef size, the estimated annual market landings were 8-9 times larger than elsewhere, and the harvest yield was 2-4 times higher than Yap and CNMI, respectively (Table 1). Daily landings were also significantly larger in Pohnpei $(P<0.01$, Dunn's tests); however, the variances in daily landings were significantly higher elsewhere $(P<0.01$ for CNMI and Yap, Levene tests). While similar high variance structures encompassed daily landing data from CNMI and Yap, the CNMI had the greatest fish demand index (514 people $\mathrm{km}^{-2}$ reef habitat), suggesting a disproportionate demand for reef fish once human population and reef size were factored in (Table 1). High demand was associated with the greatest dependence upon favorable environments for catch success in the CNMI. Low wave heights were the strongest individual predictors of daily fish biomass, followed by lunar illumination $\left(R^{2}=0.29\right.$ multiple regression model, $P<0.001$; Table 2). In contrast, Yap had the lowest human population, moderate levels of harvest yield, and comparatively low levels of reef fish demand and value indices. In Yap, only $6 \%$ of the variance in daily fish biomass was predicted by environmental regimes, with wave height, wind, and lunar illumination all significant contributors $\left(R^{2}=0.06, P=0.004\right.$, multiple regression model). Thus, the high variance structure was an artifact of high demand in the CNMI, while variable supply (i.e., effort) appears to have driven daily landings in Yap.

\section{Catch composition}

Generally, surgeonfish and unicornfish (Acanthuridae) accounted for the majority of the daily marketed fish biomass on Pohnpei, Guam (freedive), and Yap, but only after excluding $B$. muricatum from the analysis, a species unique to the commercial fisheries in Yap only (Fig. 2). In contrast, parrotfish (Scaridae) (this term used to represent the Scarinae subfamily of the wrasses for consistency with the doctrine cited throughout) dominated the CNMI and Guam landings. Heterogeneous variances associated with the multivariate catch data were also found (PERMDISP $F$-statistic $=9.21$, $P<0.001)$. High, but statistically similar variance structure was observed for CNMI and Yap (PERMDISP $t$-statistic $=0.13, P>0.05$; Fig. 3 ), while daily landings in Pohnpei had significantly less variability than others (PERMDISP $t$-statistic $>3.1, P<0.001$, for both pairwise comparisons). Compositional differences were evident between CNMI and Pohnpei (Fig. 2, ANOSIM, $R$-statistic $=0.52, P<0.01)$ due to the dominance of parrotfish (Scaridae) in CNMI catches, and greater abundances of higher trophic level families in Pohnpei (Serranidae, Lutjanidae, Carangidae, Lethrinidae; Fig. 3). Yap catches were not significantly different in composition from Pohnpei; however, pairwise differences with CNMI were noted (Fig. 4, PERMANOVA $F$-statistic $=2.7, P<0.01$ ) again due to a dominance of parrotfish in the CNMI and more acanthurids and carnivorous families in Yap. Notably, these significant differences were found whether or not B. muricatum was included in the multivariate analyses.

For islands where demographic data were available (Guam, CNMI, and Yap), over 150 species were found, yet only a small number of species, or species complexes (13-16), made up a large portion (70\%) of the total biomass (Fig. 4). The most abundant species caught for commercial sales were herbivores, large browsers (N. unicornis, $N$. lituratus, $K$. cinerascens, and $K$. vaigiensis), large- and medium-bodied excavators (C. microrhinos and C. sordidus), and large-bodied scrapers (Hipposcarus longiceps). The only common nonherbivore species caught were Monotaxis grandoculus, Lethrinus harak, and Caranx melampygus, the fourth most landed fish on Guam. Notably, Scarus rubroviolaceus, a large-bodied scraping parrotfish, made up nearly $15 \%$ of the total catch on CNMI, but was rarely recorded elsewhere.

Six species commonly targeted in all jurisdictions had the largest body sizes, or sizes similar to the largest population distribution, in $Y a p(P<0.05$, comparative tests, Fig. 5). The 
Table 2 Regression models highlighting the dependence of daily fish landing upon environmental regimes

\begin{tabular}{|c|c|c|c|c|c|c|c|c|c|}
\hline Model fit & Variables & Slope (1) & SE & Slope (2) & SE & Intercept & $R^{2}$ & $P$ value & AIC (wt) \\
\hline \multicolumn{10}{|l|}{ CNMI } \\
\hline 1 & $\log ($ wave height $)$ & -890.2 & 243.8 & - & - & $1,021.9$ & 0.29 & $<0.001$ & $511.1(0.69)$ \\
\hline 2 & $\log ($ wave height $) \times \%$ moon illumination & -875.2 & 265.3 & - & - & 947.8 & 0.26 & 0.002 & $513.1(0.25)$ \\
\hline 3 & $\%$ moon illumination & -579.3 & 221.3 & - & - & $1,036.7$ & 0.18 & 0.013 & $516.3(0.05)$ \\
\hline \multicolumn{10}{|l|}{ Yap } \\
\hline 1 & Wave height $\times \%$ illumination $\times \log ($ wind $)$ & -31.9 & 11.1 & - & - & 244.1 & 0.06 & 0.004 & $1,738(0.82)$ \\
\hline 2 & $\%$ illumination & -84.6 & 36.5 & - & - & 247.5 & 0.04 & 0.02 & $1,741(0.18)$ \\
\hline \multicolumn{10}{|l|}{ Pohnpei } \\
\hline 1 & $\log ($ moon age $) \times$ wave height $+\%$ illumination & -112.8 & 31.7 & -12.6 & 5.5 & 343.1 & 0.17 & $<0.001$ & $1,530(0.88)$ \\
\hline 2 & $\%$ illumination & -133.5 & 30.9 & - & - & 297.4 & 0.14 & $<0.001$ & $1,534(0.12)$ \\
\hline 3 & $\log ($ moon age $) \times$ wave height & -18.1 & 5.5 & - & - & 308.7 & 0.08 & 0.001 & $1,540(0.00)$ \\
\hline
\end{tabular}

Model fit refers to the amount of variance accounted for while considering the structure and stability of the model (Akaike information criterion with model weight shown in parentheses)

Fig. 2 Catch composition comparisons for major reef fish families. Black diagonal lines on the top of the Scaridae bar for Yap indicate the unique contribution of the green bumphead parrotfish (Bolbometopon muricatum), not encountered or prohibited for sales elsewhere

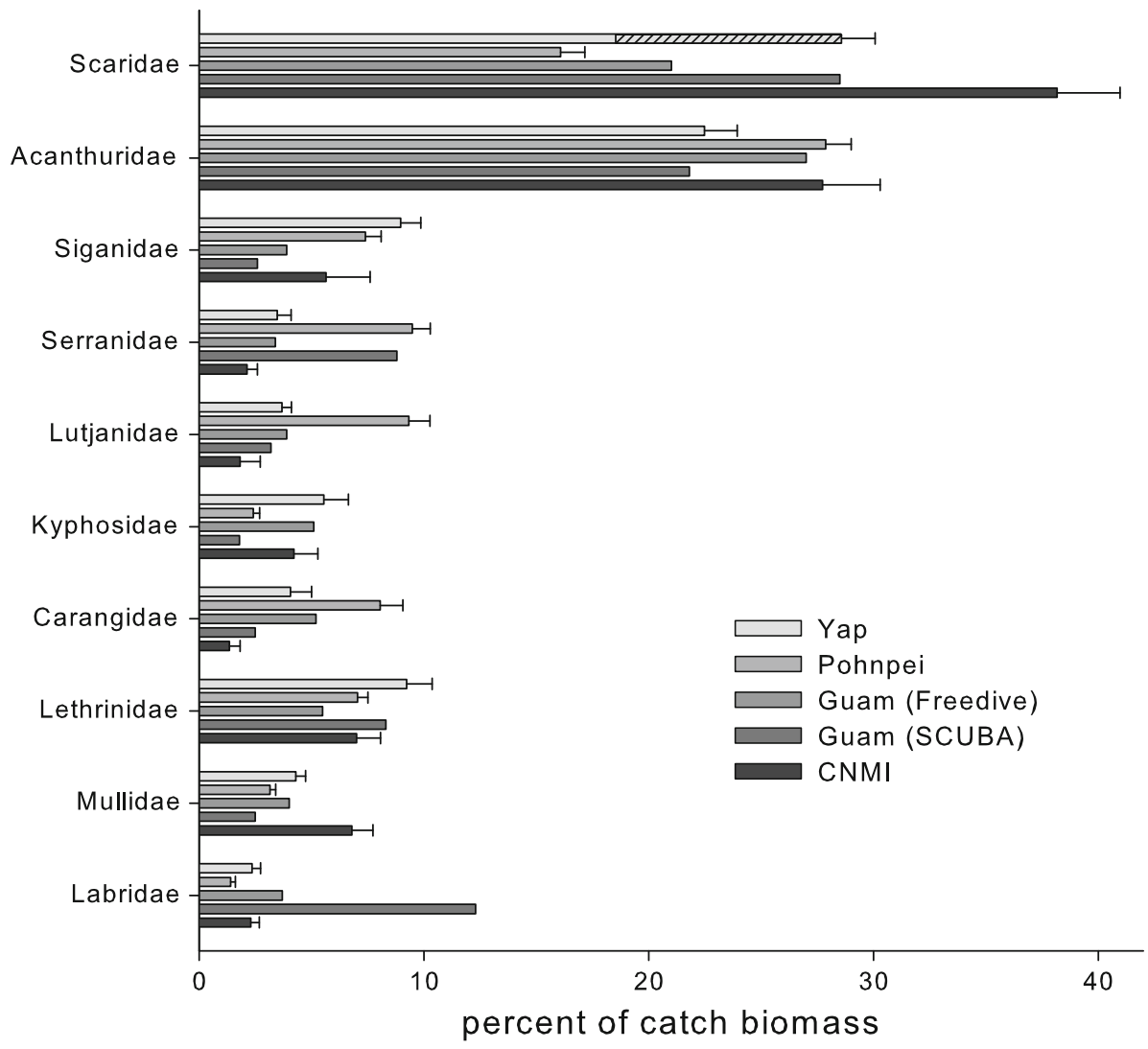

bluespine unicornfish, $N$. unicornis, was the most ubiquitous fish landed throughout Micronesia. In the CNMI and Guam, 90 and $75 \%$ of all $N$. unicornis were harvested below the reported $L_{50}$ and were significantly smaller than in Yap ( $P<0.01$, comparative tests, Fig. 5). Other commonly targeted fish, including rudderfish and yellowfin surgeonfish, Kyphosus spp. and Acanthurus xanthopterus, were also harvested below the $L_{50}$ in all jurisdictions ( $P<0.01$, comparative tests, Fig. 5). Harvested populations of B. muricatum and $C$. undulatus on Yap were both significantly below the reported $L_{50}(P<0.01$, comparative tests, Fig. 6). High biomass-to-occurrence ratios for these fish highlight their desirability and strong influence on market sales (Fig. 7). In Guam, where $C$. undulatus was too rare to examine the size, the biomass-to-occurrence ratio was found to be six times higher than Yap. In CNMI, only four humphead wrasses were recorded from a total of 11,500 fish measurements; it is too rare to examine size distributions or biomass-to-occurrence ratios. 


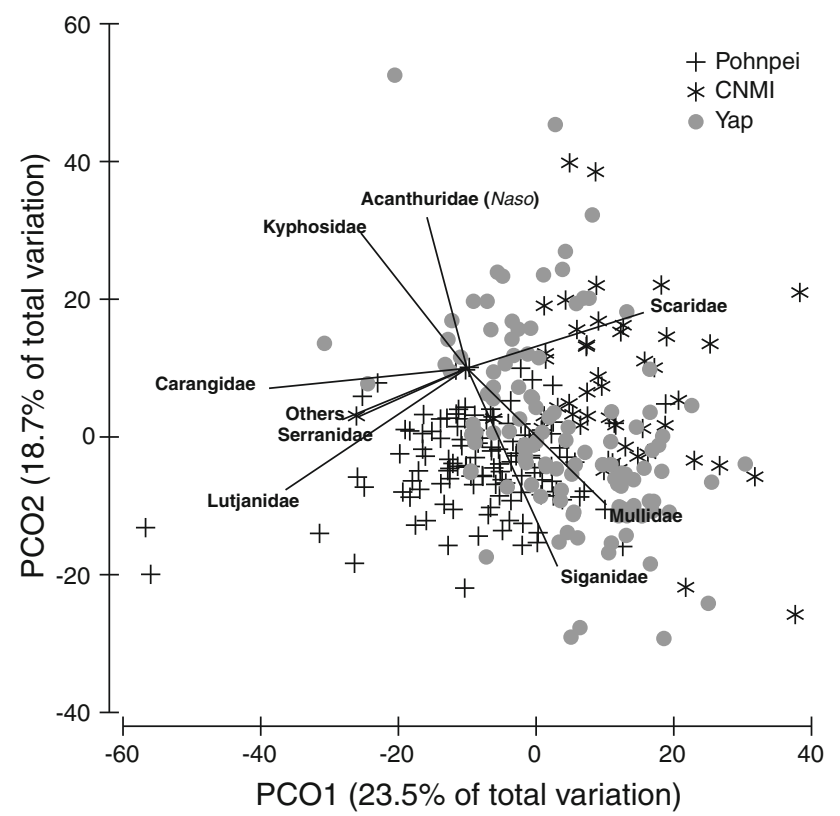

Fig. 3 Principal components ordination plot highlighting the differences in daily fish landings from each jurisdiction. Each data point represents a daily landing. The plot was created using percent contributions from all major fish families encountered

In culmination, between nine and eleven species were identified as having a biomass-to-occurrence ratio greater than 2:1 for each jurisdiction. Herbivores made up 50\% of all the species noted to have high biomass-to-occurrence ratios, along with a mixture of larger-bodied carnivores from several families.

\section{Discussion}

This study reports that indicators of high and unsustainable fishing pressure exist across Micronesia; however, the magnitude and nature differ. Overall, decreasing trophic levels and size-at-capture, as well as increasing catch variability, were evident in accordance with demand indices. While reef-fish landings from all jurisdictions were dominated by herbivores, these trends were most prevalent in the CNMI, where weather patterns best determined fishing success and high human-population-per-reef-area existed. Further, the mean size-at-capture for targeted fish decreased similarly, as larger fish were consistently found in Yap compared with CNMI and Guam. Yet, even on Yap where human population is lowest and reef size is moderate, many desirable species were harvested below their mean reproductive sizes, including the iconic green bumphead parrotfish and humphead wrasse, as well as several other common herbivores. The collective trends have known affiliations with high fishing effort, decreased catch-per-unit-effort, less sustainable fishery yields, diminished stocks, and reduced ecological function on coral reefs (Jennings and Polunin 1996; Pauly et al. 1998; Jennings and Greenstreet 1999; Graham et al. 2005; Cinner and McClanahan 2006; Anderson et al. 2008a; Lokrantz et al. 2008; McClanahan 2010). Clearly, there is a high demand for reef fish throughout Micronesia, and as demand for any exhaustible resources grows, exploitation intensity increases (Hotelling 1991). However, what are the ecological and regulatory consequences of placing a high demand upon limited reef-fish stocks, and how can these best be addressed?

In Pohnpei, although reef habitat is 2-3 times larger than other islands, marketed fish biomass was disproportionally 8-9 times greater. Cleary, the enhanced reef size and habitat availability in Pohnpei are expected to increase fishery yields, and the greater abundances of higher trophic level fish compared with other jurisdictions provide supporting evidence (McClanahan et al. 2008). However, the present study found that low lunar illumination was a significant predictor of daily market landings, with combined models accounting for $17 \%$ of the variance; a substantial finding considering that effort data were not available to factor in as a covariate (Graham 1994). Further, Rhodes and Tupper (2007) previously found unsustainable harvesting trends for groupers (Serranidae: Epinephelinae), as market landings were dominated by reproductively immature individuals. While Pohnpei has the greatest potential for reef fisheries among the jurisdictions examined, the disproportionally high harvest yields, environmentally driven success, and previously published doctrine collectively suggest current harvesting levels are unsustainable. Coupling our results with the existing doctrine, predicted reductions in trophic levels, catch-per-unit-effort, and ecological function are posited without a shift in harvesting patterns and policies (Jennings and Polunin 1996; Dulvy et al. 2004; Graham et al. 2005; Anderson et al. 2008a; McClanahan 2010). This situation in Pohnpei appears to be driven, in part, by an artificially low cost for reef fish. Market prices have remained low and stagnant for more than a decade, while external commodity prices continue to increase (Rhodes et al. 2008).

In the CNMI, SCUBA fishing has been illegal since 2002. Nonetheless, CNMI catch composition was similar to SCUBA-derived catches from Guam, supporting anecdotal information that illegal SCUBA supplied the majority of marketed fish. In support of this notion, CNMI catch composition was also markedly different from free-dive harvesting in Guam, Yap, and Pohnpei. This observation was based on a reduction in the evenness of catch across major fish families, and the dominance of parrotfish (Scaridae) that were prevalent in SCUBA-derived catches (Green 2003). It appears that as demand reaches a 
Fig. 4 Percent contribution of reef fish that accounted for the top $70 \%$ of the total landings in CNMI, Guam, and Yap. Species are grouped together if:

(1) species-level identifications were not certain during data collection, and/or (2) if total fish length and estimated size at reproduction are similar. Only species, or species complexes, with a frequency of encounter greater than $1 \%$ were included (see "Methods")

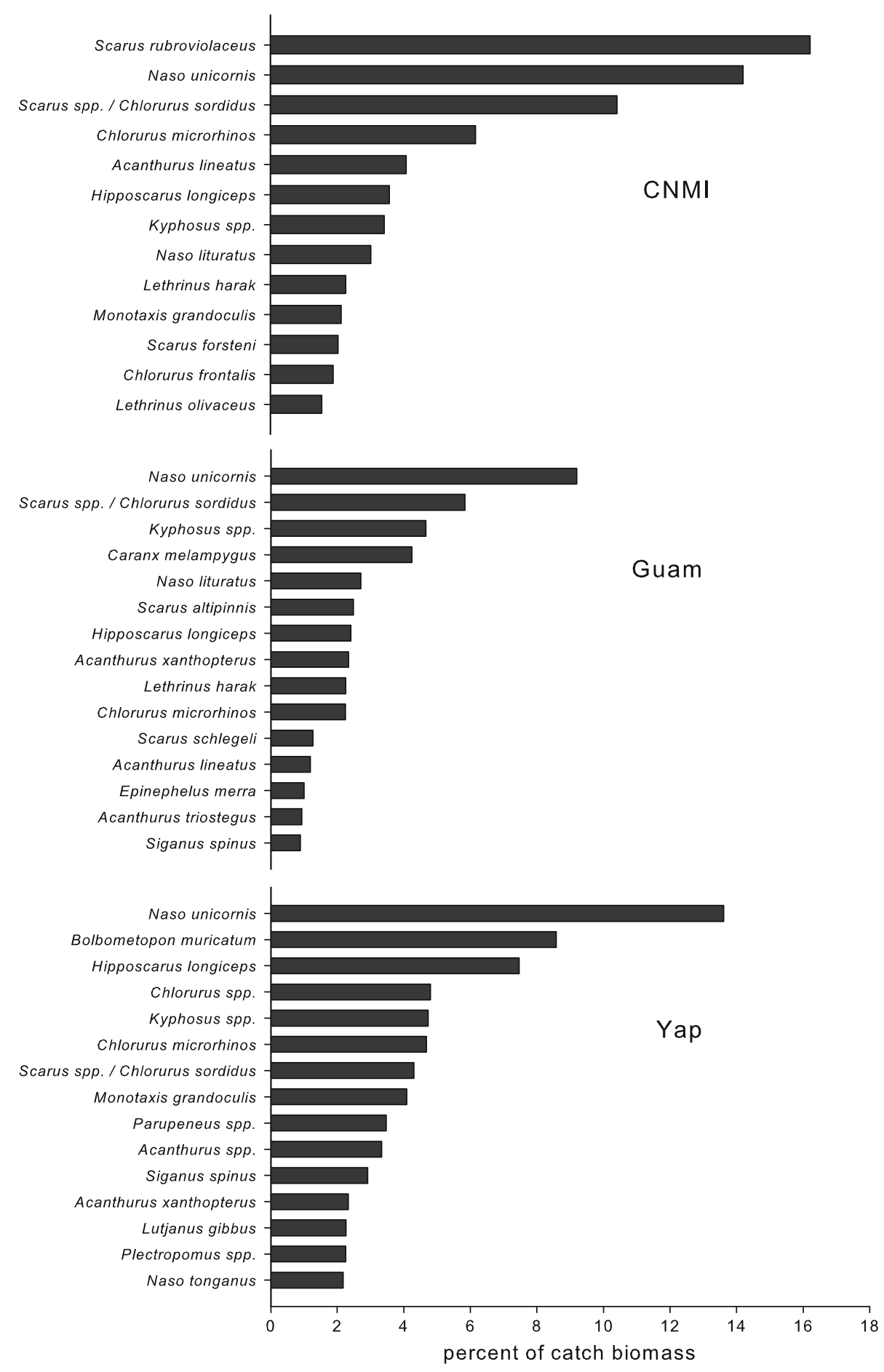

Despite the likely use of illegal SCUBA fishing techniques in CNMI, and its legal use in Guam, significantly smaller sizes of many target reef fish were reported in comparison with Yap and the known size at reproductive maturity $\left(L_{50}\right)$. This is alarming considering that deeper waters act as refuges from fishing pressure and support fish assemblages that are comparable with long-standing, no-take marine protected areas (Tyler et al. 2009; Goetze 
Fig. 5 Cumulative size-atcapture summaries for six prominent reef fish that accounted for a majority of the overall biomass delivered to commercial markets throughout Micronesia. Statistically different population distributions are indicated (*, $P<0.01$, Kruskal-Wallis tests), all others were similar. Statistical comparisons against the generated $L_{50}$ distributions, or reported size at reproduction are also shown. The vertical dashed line indicates the mean $L_{50}$. Letters indicate whether the island populations were above (a) or below (b) the $L_{50}$, while the subscripts indicate whether parametric $t$-tests (1) or nonparametric Mann-Whitney $U$-tests (2) were conducted $(P<0.01$ in all instances). Sample sizes are reported next to fish names for CNMI, Guam, and Yap, respectively
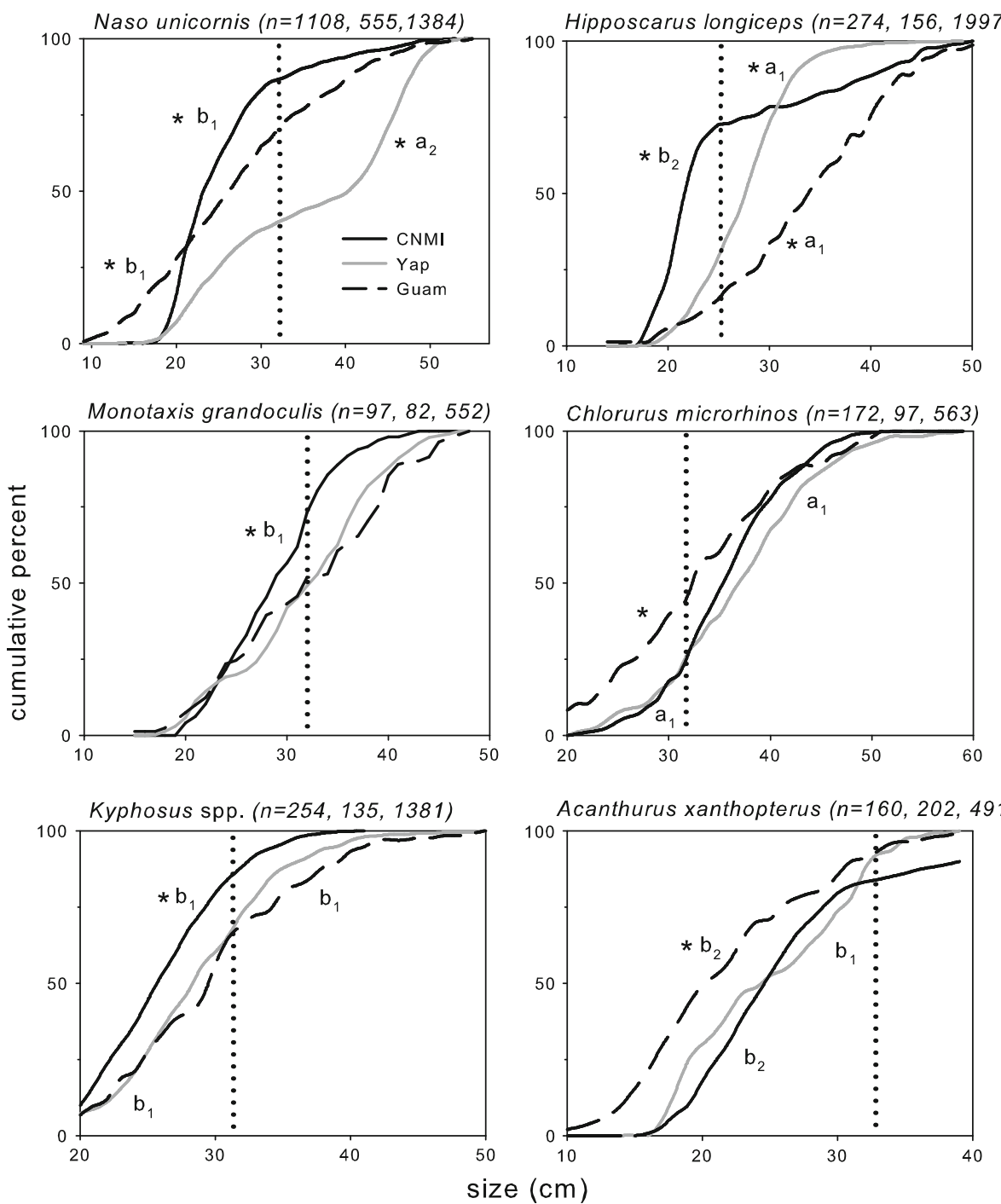

et al. 2011). Further evidence of high fishing pressure stems from the fact that iconic species such as Cheilinus undulatus were rare from Guam and CNMI landings, and common herbivores with relatively long life spans and delayed maturity, such as Chlorurus microrhinos and Scarus rubroviolaceus, were among species with the highest biomassto-frequency-of-occurrence ratios. These findings are corroborated by decreasing coastal fisheries trends in Guam over the past decades, and decreasing catch-per-unit-effort reported in southern CNMI during the 1990s (Graham 1994; Richmond et al. 2008). Informal comparisons between the present findings and Graham (1994) highlight decreasing trophic levels and mean body size for many targeted fish in the CNMI. Lastly, in situ surveys from Laolao Bay, CNMI, found significant reductions in reef-fish density and functional diversity since 1992 on shallow reef slopes, with a shift from longer-lived, late-maturing species to small acanthurids (Houk et al. 2011). Taken together, the cumulative evidence suggests that CNMI and Guam have size-spectra,

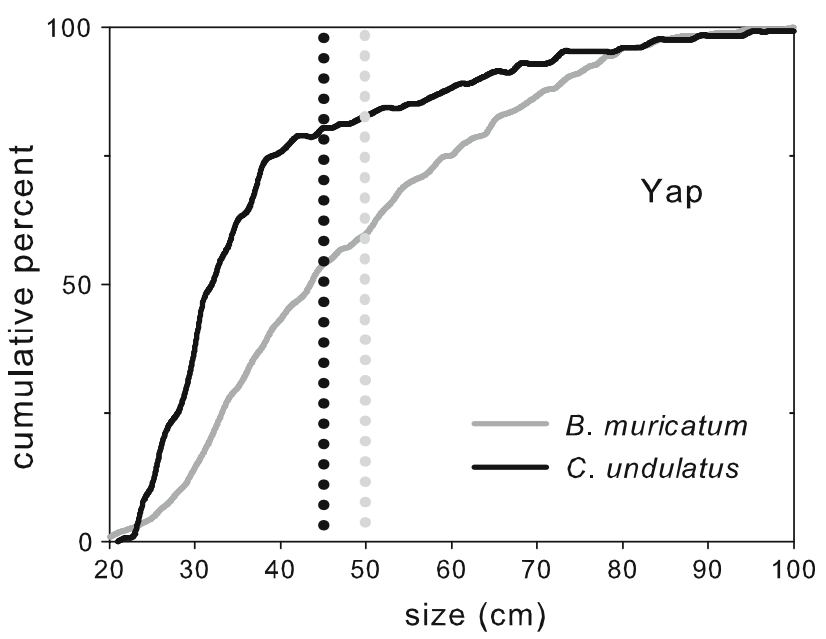

Fig. 6 Size-at-capture summaries for two iconic fish, Bolbometopon muricatum and Cheilinus undulatus, from Yap. Both fish were too rare, or absent, in catch datasets from other islands, preventing regional comparisons. Dashed lines represent the mean reproductive sizes $\left(L_{50}\right)$; in both instances, populations were harvested below their reported $L_{50}(P<0.01, t$-tests $)$ 
Fig. 7 Fish with the highest ratios of percent biomass-tooccurrence (bottom axis), highlighting influential fish for sales that were seen in relatively low frequency. Small black bars indicate the frequency of occurrence (top axis). Species with a frequency of occurrence less than $0.25 \%$ were excluded as data were too limited to address extremely rare species sighted once, or a few times only

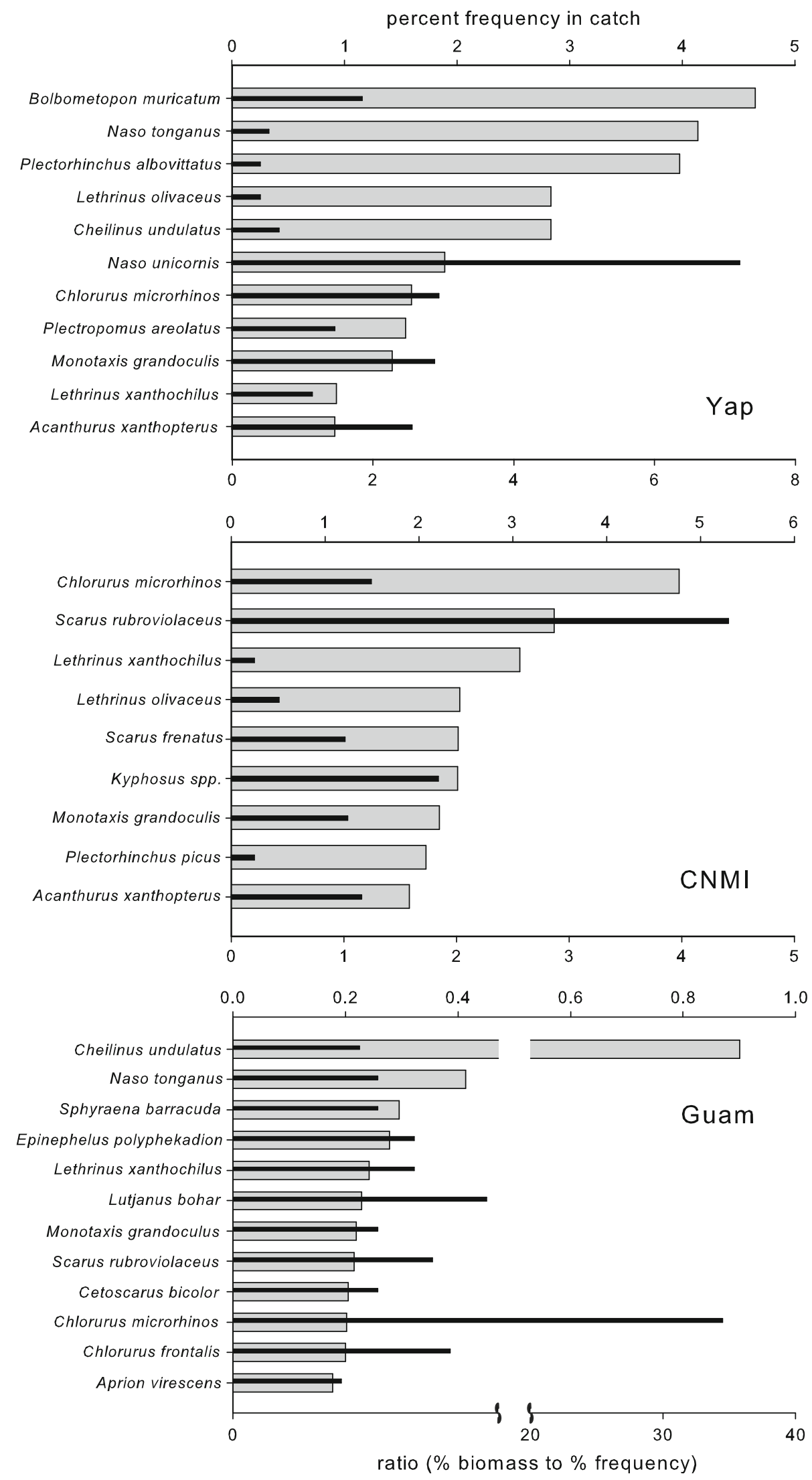


trophic composition, and/or catch frequencies of numerous target fish that are indicators of high fishery pressure, reduced stock abundances, and diminished ecological function (Jennings et al. 1998; Jennings and Greenstreet 1999; Dulvy et al. 2004; Graham et al. 2005).

Yap has the lowest human population and reliance upon reef fish for financial gain. However, two iconic fish that are reported on the IUCN red list as threatened, B. $m u$ ricatum and C. undulatus (Russell 2004; Chan et al. 2007), made up a disproportionate amount of the catch biomass, and were harvested below their mean reproductive sizes. Similar observations were made for other target herbivores, such as Kyphosus spp. and large-bodied acanthurids. While recent field surveys by Clifton et al. (2009) showed moderate population densities for these species (abundance ranks $>3$ in all instances, using 1-low to 5-high observational scale), high catch rates with no restrictions regarding quantity or size will reduce the size at capture, and ultimately reduce adult fish stocks (Berkeley et al. 2004; Birkeland and Dayton 2005; Williams et al. 2008). In comparison with other jurisdictions, Yap is perceived to have the most favorable fishery status, yet baselines and perceptions are relative in time and in nature (Knowlton and Jackson 2008). Historical fisher interviews in Yap between 1991 and 1992 had already recorded a consensus of lower catch-per-unit-effort, decreased sizes and stocks, and a need for improving management (Graham 1992). The introduction of new fishing techniques, spearguns, flashlights, and monofilament nets, were thought to be drivers of these trends, especially salient as traditional management and law do not encompass modern technology.

\section{Improving catch-based controls}

Throughout the study region, there are no legislative policies regarding the size or quantity of fish that can be harvested, prompting fishers to increase effort in order to match demand, while placing a heavy reliance upon area and gear-based management to sustain local stocks. While the multi-species nature of coral-reef fisheries has generally confounded the concept of catch-based management (Roberts and Polunin 1991; Medley et al. 1993), we report that 12-15 species, or complexes of species with similar life histories, comprised $70 \%$ of the fish landings in each jurisdiction. Thus, we argue that both catch size and quota policies are feasible; and provisions initially enforced through the few public markets on each island have the potential to begin improving Micronesian fisheries. Indeed, studies confirm optimal fishery sustainability and management by combining diverse, relevant approaches, that are inclusive of catch-based policies (Rhodes and Tupper 2007; Worm et al. 2009).
Because similar target species were reported in high abundance across Micronesia, we suggest that a regional approach toward defining improved management policies would be most effective. Such measures are aimed at increasing not only the number of fish landed, but also profitability for local fishers (McClanahan 2010). Coralreef fisheries support tourism industries, subsistence livelihoods, the fishing industry, and coral-reef ecosystem integrity (Costanza et al. 1997; Brander et al. 2007; Bell et al. 2010). Clearly, their improved management is tied to Micronesia's prosperity and livelihood.

Acknowledgments Financial support for this project was provided by The Nature Conservancy Micronesia Program. Catch data for Guam were provided by the U.S. Fish and Wildlife Service Sports Fish Restoration Program, the Pacific Islands Fisheries Science Center WPacFIN program, and the Department of Agriculture's Division of Aquatic and Wildlife Resources. Catch data in the CNMI were collected in collaboration with several grants under their territorial Coral Reef Initiative and monitoring programs, administered through the NOAA Coral Program. Catch data from Yap were collected in association with a David and Lucille Packard Foundation grant to Yap Community Action Program, while analyses were supported, in part, by a National Oceanic and Atmospheric Administration (NOAA) General Coral Reef Conservation Program (GCRCP) to $\mathrm{PH}$. Catch data from Pohnpei were supported through a NOAA GCRCP awarded to KR. The authors are grateful for the dedication of numerous individuals across Micronesia that have been collecting fishery-dependent data. Finally, thanks to three external reviewers that provided beneficial comments to improve our work and helped maintain professionalism throughout a difficult review process.

\section{References}

Anderson CNK, Hsieh CH, Sandin SA, Hewitt R, Hollowed A, Beddington J, May RM, Sugihara G (2008a) Why fishing magnifies fluctuations in fish abundance. Nature 452:835-839

Anderson M, Gorley R, Clarke K (2008b) PERMANOVA+ for PRIMER: Guide to software and statistical methods. PRIMER-E Ltd, Plymouth, UK

Bell JD, Kronen M, Vunisea A, Nash WJ, Keeble G, Demmke A, Pontifex S, Andrefouet S (2010) Planning the use of fish for food security in the Pacific. Mar Policy 33:64-76

Berkeley SA, Hixon MA, Larson RJ, Love MS (2004) Fisheries Sustainability via protection of age structure and spatial distribution of fish populations. Fisheries 29:23-32

Birkeland C (2004) Ratcheting down the coral reefs. Bioscience 54:1021-1027

Birkeland C, Dayton PK (2005) The importance in fishery management of leaving the big ones. Trends Ecol Evol 20:356-358

Brander L, Van Beukering P, Cesar H (2007) The recreational value of coral reefs: a meta-analysis. Ecol Econ 63:209-218

Brewer T, Cinner J, Green A, Pandolfi J (2009) Thresholds and multiple scale interaction of environment, resource use, and market proximity on reef fishery resources in the Solomon Islands. Biol Conserv 142:1797-1807

Caddy J, Seijo J (2005) This is more difficult than we thought! The responsibility of scientists, managers and stakeholders to mitigate the unsustainability of marine fisheries. Philos Trans R Soc Lond B 360:59-75 
Chan T, Sadovy Y, Donaldson T (2007) Bolbometopon muricatum. IUCN Red List of Threatened Species. http://www.iucnredlist.org

Choat JH, Axe LM, Lou DC (1996) Growth and longevity in fishes of the family Scaridae. Mar Ecol Prog Ser 145:33-41

Cinner J, McClanahan T (2006) Socioeconomic factors that lead to overfishing in small-scale coral reef fisheries of Papua New Guinea. Environ Conserv 33:73-80

Clarke KR, Warwick RM (2001) Change in marine communities: an approach to statistical analysis and interpretation. PRIMER-E Ltd, Plymouth, UK

Clifton K, Dubey E, Woodburn E (2009) A quantitative assessment of reef fish distribution and abundance within near-shore reef habitats of Yap State, FSM. J Ocean Sci Foundat 2:1-18

Costanza R, Arge R, de Groot R, Farber S, Grasso M, Hannon B, Limburg K, Naeem S, Oneill RV, Paruelo J, Raskin RG, Sutton P, van den Belt M (1997) The value of the world's ecosystem services and natural capital. Nature 387:253-260

Crawley M (2007) The R book. John Wiley \& Sons Inc, West Sussix, England

Dahl C (1988) Traditional marine tenure. A basis for artisanal fisheries management. Mar Policy 1:40-48

Dalzell P, Adams T, Polunin N (1996) Coastal fisheries in the Pacific Islands. Oceanogr Mar Biol Annu Rev 34:395-531

Dulvy N, Polunin N, Mill A, Graham N (2004) Size structural change in lightly exploited coral reef fish communities: evidence for weak indirect effects. Can J Fish Aquat Sci 61:466-475

Eldredge LG (1983) Summary of environmental and fishing information on Guam and the Commonwealth of the Northern Mariana Islands: Historical background, description of the islands, and review of climate, oceanography, and submarine topography around Guam and the Northern Mariana Islands. NOAA-TM-NMFS-SWFC-40, Honolulu

Folke C, Carpenter S, Walker B, Scheffer M, Elmqvist T, Gunderson L, Holling C (2004) Regime shifts, resilience, and biodiversity in ecosystem management. Annu Rev Ecol Evol Syst 35:557-581

Froese R, Binohlan C (2000) Empirical relationships to estimate asymptotic length, length at first maturity and length at maximum yield per recruit in fishes, with a simple method to evaluate length frequency data. J Fish Biol 56:758-773

Goetze J, Langlois T, Egli D, Harvey E (2011) Evidence of artisanal fishing impacts and depth refuge in assemblages of Fijian reef fish. Coral Reefs 30:507-517

Graham T (1992) The application of traditional rights-based fishing systems to contemporary problems in fisheries management. A focus on the Pacific basin. M.Sc. thesis, Oregon State University, p 95

Graham T (1994) Biological analysis of the nearshore reef fish fishery of Saipan and Tinian. CNMI Division of Fish and Wildlife Technical Report 94-02, Saipan, MP

Graham N, Dulvy N, Jennings S, Polunin N (2005) Size-spectra as indicators of the effects of fishing on coral reef fish assemblages. Coral Reefs 24:118-124

Green A (2003) American Samoa bans destructive SCUBA fishery: The role of monitoring in management. In: Wilkinson $\mathrm{C}$, Green A, Almany J, Dionne S (eds) Monitoring coral reef marine protected areas. Australian Institute of Marine Science IUCN Marine Program, Townsville, Australia

Hamilton R, Adams S, Choat J (2008) Sexual development and reproductive demography of the green humphead parrotfish (Bolbometopon muricatum) in the Solomon Islands. Coral Reefs 27:153-163

Heupel MR, Williams AJ, Welch DJ, Davies CR, Adams S, Carlos G, Mapstone BD (2010) Demography of a large exploited grouper, Plectropomus laevis: Implications for fisheries management. Mar Freshw Res 61:184-195
Hopkins KD, Rhodes KL (2010) A field and household assessment of non-commercial fishing, per capita consumption and trade patterns for coral reef fisheries management improvement in Pohnpei, Micronesia. Technical report submitted to National Oceanic and Atmospheric Administration (NA08NMF4630458), Silver Springs, MD

Hotelling H (1991) The economics of exhaustible resources. Bull Math Biol 53:281-312

Houk P, Musburger C, Wiles P (2010) Water quality and herbivory interactively drive coral-reef recovery patterns in American Samoa. PloS ONE 5:e13913

Houk P, Okano R, Iguel J, Camacho R, Benavente D, Johnson S (2011) Laolao Bay road and coastal management improvement project. Ecological and water quality assessment. CNMI Division of Environmental Quality Technical Report, Saipan, MP

Hsieh C, Reiss C, Hunter J, Beddington J, May R, Sugihara G (2006) Fishing elevates variability in the abundance of exploited species. Nature 443:859-862

Jennings S, Greenstreet S (1999) Structural change in an exploited fish community: a consequence of differential fishing effects on species with contrasting life histories. J Anim Ecol 68:617-627

Jennings S, Kaiser M (1998) The effects of fishing on marine ecosystems. Adv Mar Biol 34:201-212

Jennings S, Polunin N (1996) Effects of fishing effort and catch rate upon the structure and biomass of Fijian reef fish communities. J Appl Ecol 33:400-412

Jennings S, Reynolds J, Mills S (1998) Life history correlates of responses to fisheries exploitation. Proc R Soc B 265:333-339

Johannes R (1978) Traditional marine conservation methods in Oceania and their demise. Annu Rev Ecol Syst 9:349-364

Johannes R (1981) Words of the lagoon: fishing and marine lore in the Palau district of Micronesia. University of California Press, Berkeley, USA

Kaunda-Arara B, Rose G, Muchiri M, Kaka R (2003) Long-term trends in coral reef fish yields and exploitation rates of commercial species from coastal Kenya. Western Indian J Mar Sci 2:105-116

Kaunda-Arara B, Mwaluma JM, Locham GA, Oresland V, Osore MK (2009) Temporal variability in fish larval supply to Malindi Marine Park, coastal Kenya. Aquat Conserv 19:S10-S18

Knowlton N, Jackson JBC (2008) Shifting baselines, local impacts, and global change on coral reefs. PLoS Biol 6:e54

Koslow J, Hanley F, Wicklund R (1988) Effects of fishing on reef fish communities at Pedro Bank and Port Royal Cays, Jamaica. Mar Ecol Prog Ser 43:201-212

Kronen M, Tafileichig A (2008) Traditional rights and management of Yap's coastal fisheries and the role of fisherwomen. SPC Women in Fisheries Information Bulletin 18:21-25

Lokrantz J, Nyström M, Thyresson M, Johansson C (2008) The nonlinear relationship between body size and function in parrotfishes. Coral Reefs 27:967-974

May R (1977) Thresholds and breakpoints in ecosystems with a multiplicity of stable states. Nature 269:471-477

May R, Beddington J, Clark C, Holt S, Laws R (1979) Management of multispecies fisheries. Science 205:267-277

McClanahan TR (1988) Seasonality in East Africa's coastal waters. Mar Ecol Prog Ser 44:191-199

McClanahan TR (2010) Effects of fisheries closures and gear restrictions on fishing income in a Kenyan coral reef. Conserv Biol 24:1519-1528

McClanahan TR, Maina J, Pet-Soede L (2002) Effects of the 1998 coral morality event on Kenyan coral reefs and fisheries. Ambio 31:543-550

McClanahan TR, Hicks CC, Darling ES (2008) Malthusian overfishing and efforts to overcome it on Kenyan coral reefs. Ecol Appl 18:1516-1529 
Medley PA, Gaudian G, Wells S (1993) Coral-reef fisheries stock assessment. Rev Fish Biol Fish 3:242-285

Newton K, Cote IM, Pilling GM, Jennings S, Dulvy NK (2007) Current and future sustainability of island coral-reef fisheries. Curr Biol 17:655-658

Pauly D, Christensen V, Dalsgaard J, Froese R, Torres FC (1998) Fishing down marine food webs. Science 279:860-863

Rhodes KL, Tupper M (2007) A preliminary market-based analysis of the Pohnpei, Micronesia, grouper (Serranidae: Epinephelinae) fishery reveals unsustainable fishing practices. Coral Reefs 26: 335-344

Rhodes KL, Tupper M, Wichilmel C (2008) Characterization and management of the commercial sector of the Pohnpei coral reef fishery, Micronesia. Coral Reefs 27:443-454

Richmond RH, Houk P, Trianni M, Wolanski E, Davis G, Bonito V, Paul VJ (2008) Aspects of biology and ecological functioning of coral reefs in Guam and the Commonwealth of the Northern Mariana Islands. In: Riegl B, Dodge RE (eds) Coral reefs of the USA. Springer, New York, pp 719-739

Roberts C, Polunin N (1991) Are marine reserves effective in management of reef fisheries? Rev Fish Biol Fish 1:65-91

Russell B (2004) Cheilinus undulatus. IUCN Red List of Threatened Species. http://www.iucnredlist.org

Sadovy de Mitcheson Y, Liu M, Suharti S (2010) Gonadal development in a giant threatened reef fish, the humphead wrasse Cheilinus undulatus, and its relationship to international trade. J Fish Biol. doi: 10.1111/j.1095-8649.2010.02714.x

Sudo K (1984) Social organization and types of sea tenure in Micronesia. Senri Ethnol Stud 17:203-230

Tsehaye I, Machiels MAM, Nagelkerke LAJ (2007) Rapid shifts in catch composition in the artisanal Red Sea reef fisheries of Eritrea. Fish Res 86:58-68
Tyler EHM, Speight MR, Henderson P, Manica A (2009) Evidence for a depth refuge effect in artisanal coral reef fisheries. Biol Conserv 142:652-667

van Beukering P, Haider W, Wolfs E, Liu Y, van der Leeuw K, Longland M, Sablan J, Beardmore B, Di Prima S, Massey E, Cesar HSJ, Hausfather Z, Gourley J (2006) The economic value of the coral reefs of Saipan, Commonwealth of the Northern Mariana Islands. Report prepared by Cesar Environmental Consulting. funded by the National Oceanic and Atmospheric Administration, Silver Springs, MD

van Beukering P, Haider W, Longland M, Cesar HSJ, Sablan J, Shjegstad S, Beardmore B, Liu Y, Garces GO (2007) The economic value of Guam's coral reefs. Report prepared by Cesar Environmental Consulting, funded by the National Oceanic and Atmospheric Administration, Silver Springs, MD

Varkey D, Ainsworth C, Pitcher T, Goram Y, Sumaila R (2010) Illegal, unreported and unregulated fisheries catch in Raja Ampat Regency, Eastern Indonesia. Mar Policy 34:228-236

Williams AJ, Currey LM, Begg GA, Murchie CD, Ballagh AC (2008) Population biology of coral trout species in eastern Torres Strait: Implications for fishery management. Cont Shelf Res 28:21292142

Worm B, Hilborn R, Baum JK, Branch TA, Collie JS, Costello C, Fogarty MJ, Fulton EA, Hutchings JA, Jennings S (2009) Rebuilding global fisheries. Science 325:578

Zar J (1999) Biostatistics. Prentice Hall, New Jersey

Zeller D, Booth S, Pauly D (2006) Fisheries contributions to the gross domestic product: underestimating small-scale fisheries in the Pacific. Mar Resour Econ 21:355-374

Zeller D, Booth S, Davis G, Pauly D (2007) Re-estimation of smallscale fishery catches for US flag-associated island areas in the western Pacific: the last 50 years. Fish Bull 105:266-277 